\title{
JUÍZES PROFISSIONAIS? \\ PADRÕES DE CARREIRA DOS INTEGRANTES DAS \\ SUPREMAS CORTES DE BRASIL (1829-2008) E ESTADOS \\ UNIDOS (1789-2008)
}

\author{
Luciano Da Ros
}

\begin{abstract}
RESUMO
O artigo compara os perfis de carreira dos magistrados integrantes das supremas cortes do Brasil e dos Estados Unidos ao longo de toda história política dos dois países. Para tanto, o artigo analisa dados relativos à experiência profissional e jurídica e à circulação em cargos junto aos demais poderes do Estado, inclusive de natureza eletiva, previamente à investidura no posto de magistrado da Corte Suprema. Particularmente, esse exame expõe as diferenças e semelhanças quanto aos padrões de profissionalização dos integrantes dos órgãos de cúpula do poder Judiciário nos dois países, permitindo a discussão sobre os fundamentos políticos desse fenômeno no campo jurídico. Em especial, o artigo sugere que períodos de incremento no recrutamento de indivíduos vinculados a profissões propriamente jurídicas ocorrem como respostas ao fortalecimento de tais tribunais. Ante um novo período de elevada proeminência destas instituições, indivíduos reconhecidamente qualificados na área passam crescentemente a ser alternativas de legitimação de tais órgãos, seja em contextos de competição, seja em contextos de hegemonia política de determinados grupos.
\end{abstract}

PALAVRAS-CHAVE: carreiras jurídicas; seleção judicial; profissionalização; profissões jurídicas.

\section{INTRODUÇ̃̃O 1}

Um dos meios mais empregados para compreender a realidade política brasileira tem sido compará-la com aquela própria dos Estados Unidos (EUA). Trata-se de perspectiva há muito presente em trabalhos de diversos cientistas sociais, como atestam as obras de autores tão distantes cronologicamente como Oliveira Vianna, Caio Prado Júnior e José Murilo de Carvalho, entre

1 Pesquisa financiada com bolsas da Coordenação de Aperfeiçoamento de Pessoal do Nível Superior (Capes) e da Comissão Fulbright, a quem o autor agradece pelo vital aporte financeiro. Versão preliminar desse trabalho foi apresentada no Grupo de Trabalho Elites e Instituições Políticas, no $32^{\circ}$ Encontro Anual da Associação Nacional de Pós-Graduação em Ciências Sociais (Anpocs), realizado em outubro de 2008 em Caxambu. Agradeço aos comentários de Renato Monseff Perissinotto e Ernesto Seidl, bem como aos editores da Revista de Sociologia e Política e aos dois pareceristas anônimos pela leitura atenta e sugestões pertinentes que seguramente contribuíram para a melhoria deste artigo. Agradeço ainda ao apoio de André Marenco dos Santos pelo estímulo à continuidade deste trabalho que começamos juntos. outros. A realidade estadunidense sempre serviu implicitamente como um modelo comparativo natural para analisar os diferentes destinos políticos das américas portuguesa e anglo-saxônica e, nos casos mais pessimistas, como uma espécie de espelho invertido para o qual se olha buscando identificar os fatores que conduziram à prosperidade de uma e não de outra ${ }^{2}$.

Na maioria dos casos, entretanto, não se chega a levar adiante uma comparação sistemática entre as duas realidades, mas apenas identificar de forma pontual diferenças entre ambas como forma de melhor desvendar o que ocorre especificamente no Brasil. O propósito deste trabalho busca afastar-se dessa tendência, colocando lado a lado duas importantes e longevas instituições de Brasil e Estados Unidos, examinando suas diferenças e semelhanças como forma de melhor compreender ambas e de discutir as questões teóricas decorrentes. Como consequência de pesquisa previa-

2 Nesse particular, destaca-se o trabalho de Morse (1988). 
mente realizada sobre os perfis de carreira dos magistrados integrantes dos órgãos de cúpula do poder Judiciário no Brasil (MARENCO DOS SANTOS \& DA ROS, 2008), este trabalho busca, portanto, comparar aqueles achados com o quadro observado no órgão similar dos EUA, a United States Supreme Court (USSC).

Semelhante comparação é viável principalmente porque ao longo de maior parte da história os dois países adotaram regras institucionais parecidas para a seleção dos magistrados de suas Cortes Supremas, priorizando a indicação pelo poder Executivo com ulterior aprovação do Senado. As exceções são os períodos de 1829-1891, 19301934 e 1937-1945 no Brasil, em que regras diferentes foram adotadas, não havendo modificações quanto a esse quesito ao longo de toda a história estadunidense. Como se verá a seguir, mesmo essas variações nas regras de seleção permitem interessantes análises, possibilitando desvendar os reais efeitos de tais regras sobre a seleção dos integrantes desses órgãos.

Para esse exame foram analisados os dados biográficos de todos os ministros do Supremo Tribunal de Justiça (STJi) (1829-1891) e do Supremo Tribunal Federal (STF) (1891-2008) no Brasil e de todos os justices da Suprema Corte nos Estados Unidos da América (1789-2008). Abrangendo um período que chega a quase 2000 anos no primeiro caso e que ultrapassa esse horizonte no segundo, o artigo busca apreender mudanças e continuidades quanto à formação acadêmica, experiência profissional e jurídica e, especialmente, quanto à circulação dos futuros magistrados em cargos junto aos demais poderes do Estado (Executivo e Legislativo), tanto de natureza eletiva como funcional, além daqueles referentes à administração da atividade coercitiva do Estado (vinculadas à gestão de atividades militares e policiais), previamente à investidura na Corte Suprema. Em particular, busca-se examinar as variações relativas à profissionalização dos integrantes dos órgãos de cúpula do poder Judiciário dos dois países, elemento que contribui para a diferenciação e institucionalização de tais órgãos (BONELLI, 2002; MCGUIRE, 2004; HELMKE, 2005).

O exame dos perfis dos integrantes dessas instituições em amplo recorte temporal, todavia, apresenta tanto pontos positivos como negativos. Por um lado, ele desvenda os tipos de carreiras priorizadas até o ingresso nos tribunais em diferentes momentos históricos de cada país, identificando os fatores que conduzem ao incremento da profissionalização de seus integrantes e, conseqüentemente, introduz a discussão teórica sobre os fundamentos políticos de tal fenômeno. Por outro lado, o período histórico demasiado longo acaba subestimando as particularidades de cada conjuntura e dos respectivos recursos que estruturam os padrões de recrutamento analisados, limitando-os ao seu aspecto institucional ${ }^{3}$.

Em vista dos argumentos apresentados acima, este estudo justifica-se basicamente por quatro razões. Primeiramente, como já salientado, tratase de uma oportunidade de discutir teoricamente os fundamentos da profissionalização dos integrantes de cortes supremas em diferentes contextos históricos, o que repercute também sobre a discussão relativa à institucionalização de tais órgãos. Em segundo lugar, o trabalho permite compreender de maneira mais adequada o próprio caso brasileiro, muitas vezes compreendido à luz de experiências estrangeiras sem que se proceda a uma comparação sistemática entre o STF e seus equivalentes estrangeiros. Em terceiro lugar, a existência, ainda que em momentos históricos delimitados, de regras distintas de nomeação de magistrados para tais tribunais permite investigar os reais efeitos dessas mesmas regras. Um dos argumentos levantado por institutional designers, acadêmicos da área jurídica e magistrados brasileiros de instâncias inferiores afirma que regras privilegiando o recrutamento endógeno à carreira judicial seriam mais desejáveis por evitar a nomeação de indivíduos vinculados a agremiações políticas específicas, o que conduziria a uma alegada partidarização de tais órgãos ${ }^{4}$. Analisar o efeito de regras distintas de nomeação sobre a profissionalização dos membros das cortes supremas, especialmente do caso brasileiro, tornase possível, portanto, acessando tais dados biográficos. Por fim, uma comparação longitudinal

\footnotetext{
3 Agradeço a um dos pareceristas anônimos da Revista de Sociologia e Política por essa observação pertinente.

4 Curiosamente, nos Estados Unidos, o conflito pela profissionalização - entendida particularmente como o incremento de indivíduos treinados em law schools - deuse principalmente na base do poder Judiciário, onde freqüentemente indivíduos sem formação jurídica exerciam funções judiciais (PROVINE, 1986).
} 
de vasto horizonte temporal permite identificar os reflexos das mudanças políticas mais gerais por que passaram os dois países ao longo de suas histórias sobre os integrantes das cortes supremas de Brasil e Estados Unidos, bem como os tipos de relações que se estabeleceram entre os demais poderes do Estado e tais tribunais.

\section{QUADRO DE ANÁLISE}

Antes de passar à análise propriamente dita dos dados empíricos coletados para esse trabalho, fazse importante delimitar o quadro teórico em que se insere essa discussão. Em particular, este trabalho pretende dialogar com trabalhos que discutem a profissionalização de elites jurídica e, em especial, as condições políticas que propiciam seu incremento.

A profissionalização no mundo do Direito tem sido compreendida como uma forma específica de exercer-se uma ocupação e de estabelecer relações no mundo do trabalho, constituindo-se uma alternativa às formas tradicionais de influência política. Valorizando o conhecimento abstrato e a expertise, a formação em instituições específicas de ensino e a crença no mérito, a idéia de autonomia funcional e a prestação de serviços com independência frente aos interesses do Estado e do mercado, o profissionalismo prega a prática de uma política distinta, que não se exerceria pelo meio tradicionalmente reconhecido para tal - $\mathrm{a}$ ação político-partidária - mas sim recorrendo ao conhecimento técnico e a valores de apelo universal que transcenderiam a política convencional (HALLIDAY, 1999, p. 1057-1059; BONELLI, 2002, p. 16-92). Com isso, o propósito seria a constituição de um espaço próprio de atuação distinto da política cotidiana, por meio do qual os profissionais do Direito influiriam politicamente sem tornarem-se contendores específicos, resguardando sua autonoia por não se identificarem com nenhum dos principais agentes políticos, em particular membros dos poderes representativos do Estado e de partidos políticos.

De uma forma mais ampla, trata-se de entender os operadores do Direito como uma policy community - a comunidade jurídica - integrante um subsistema político específico - as instituições encarregadas da interpretação das regras jurídicas, o chamado sistema de justiça ${ }^{5}$. O propósito deste

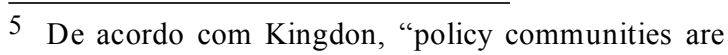

trabalho é compreender as condições que levaram indivíduos que priorizaram a circulação por essa arena (e não por outras, como a política-partidária, por exemplo) a serem alçados ao posto de juiz na Corte Suprema de cada país. Isso posto, as idéias de profissionalização e expertise são empregadas aqui apenas para expressar a maior vinculação dos indivíduos a esse universo próprio da comunidade jurídica que, por sua vez, difere-se de outras esfereas, como a político-partidária e a diretamente coercitiva $^{6}$.

Magistrados integrantes de cortes supremas, todavia, situam-se em um contexto politicamente sensível, que não lhes facilita a construção de um espaço próprio de atuação muito distante das fronteiras delimitadas por políticos e legisladores. Tanto no Brasil quanto nos EUA, e a exemplo do que ocorre na maior parte do mundo, o processo de nomeação dos integrantes desses tribunais é profundamente permeado por elementos políticopartidários, em especial se comparado ao que ocorre nas instâncias inferiores da maioria das profissões jurídicas, majoritariamente burocratizadas ${ }^{7}$. Como será visto, as regras de seleção

composed of specialists in a given policy area" "as comunidades políticas são compostas de especialistas em uma dada área política" (KINGDON, 2003, p. 117; as traduções são de responsabilidade do revisor). Para uma discussão mais aprofundada sobre policy communities, veja-se Kingdon (idem, p. 117-131), Baumgartner e Jones (2009, p. 4-9), entre outros.

6 Embora a discussão sobre a ideia propriamente dita de profissão seja obviamente importante, como este artigo a emprega de forma mais vaga, não parece caber aqui uma pormenorização maior sobre o tema. Nesse sentido, embora seja verdade que os universos profissionais sejam definidos especialmente em relação ao Estado no Brasil (veja-se, em particular, o conceito de cidadania regulada de Santos (1979)) e que o mercado ocupe lugar mais central nos Estados Unidos, em ambos os casos o que os advogados do profissionalismo propoem é uma separação maior em relação tanto ao mercado quanto ao estado (BONELLI, 2002). Agradeço a um dos pareceristas anônimos da Revista de Sociologia e Política por essa sugestão pertinente.

7 Convém observar, todavia, que o cargo de magistrado nos Estados Unidos, tanto no âmbito estadual como federal, é explicitamente pautado pelos vínculos expressos com a política partidária, especialmente porque inexiste magistratura burocratizada, como na maior parte dos países europeus e latino-americanos (veja-se, por exemplo, Guarnieri e Pederzoli (1996); Lyles (1997) e, mais genericamente, o volume editado por Malleson e Russell (2006)). 
existentes nos Brasil e nos EUA conferem razoável dose de discricionariedade aos atores políticos no interior dos poderes Executivo e Legislativo e pouco espaço às profissões jurídicas, ao menos do ponto de vista formal. Nesse contexto, a possibilidade de nomeação de indivíduos afiliados a agremiações políticas específicas, independentemente de seu mérito, expertise e crença nos valores que compartilham os demais juristas - isto é, independentemente de seu reconhecimento pela comunidade jurídica - certamente não é diminuta. Nesse sentido, cumpre observar que a noção de elite judicial é empregada livremente neste trabalho apenas para ilustrar os indivíduos que ascenderam ao topo da hierarquia institucional do poder Judiciário

Mapeando as motivações judiciais dos integrantes da Corte Suprema de Justicia da Argentina, Gretchen Helmke identificou justamente que juristas profissionais, entendidos como aqueles "primarily concerned with his or her image in the legal community"8 (HELMKE, 2005, p. 34), são apenas um tipo de magistrado dos órgãos de cúpula do poder Judiciário, ao lado de policy seekers, que atuariam a partir de ideologias políticopartidárias claras, e de carreiristas, que orientam sua atuação no tribunal para ascenderem em suas carreiras uma vez deixem a instituição. No caso, a promoção do profissionalismo entre os integrantes de cortes supremas encontrar-se-ia vinculada tanto à reputação que estes desfrutam junto à comunidade jurídica quanto à legitimidade institucional do órgão que integram. Esse perfil conectar-se-ia, portanto, à idéia de uma "corte institucionalista", preocupada com a manutenção de sua autonomia e integridade institucional ante as possíveis ingerências dos poderes eletivos (HELMKE \& SANDERS, 2006, p. 870-871) e também a uma atuação próxima ao que se considera a sua "missão institucional", promovendo valores e idéias sensíveis à classe jurídica, como o constitucionalismo ou os direitos humanos (GILLMAN, 1993; KECK, 2007). Esses indivíduos, em resumo, seriam mais diretamente "accountable to the legal profession", como sintetiza Provine (1986, p. XIII). Entretanto,

\footnotetext{
8 "Primariamente preocupados com sua imagem na comunidade legal" (N.R.).

9 “responderiam à profissão jurídica” (N.R.).
}

encontrar em tais órgãos indivíduos cujas carreiras vinculem-nos mais ao universo jurídico e menos a outras arenas não é um dado imediato da realidade e depende grandemente da vontade de atores políticos para acontecer.

A nomeação de indivíduos com perfil jurídicoprofissional para órgãos de cúpula do poder Judiciário não depende, portanto, apenas da vontade das profissões jurídicas. Para que estas sejam contempladas com a indicação de juristas de carreira às Cortes Supremas nos diferentes países - isto é, para que a profissionalização seja atingida em tais casos - contextos específicos se fazem necessários. Discutir as condições para tanto a partir do exame das realidades brasileira e norte-americana é a questão que ocupa esse estudo. Tal discussão integra o debate mais amplo sobre os fundamentos da emergência do profissionalismo no interior do Estado, colocandoo não apenas como um recurso ideológico ou retórico a ser empregado por elites profissionais contra políticos como forma de definir um espaço de atuação à margem destes, mas também como um curso de ação que pode ser estimulado pelo próprio conjunto de forças políticas em contextos específicos.

Isso posto, o objetivo deste trabalho não é demonstrar que há predomínio da expertise sobre outros recursos nas carreiras dos integrantes das cortes supremas de Brasil e Estados Unidos. Ao contrário, como se verá em seguida, a maioria dos magistrados de tais órgãos apresentaram carreiras nada ortodoxas do ponto de vista estritamente jurídico. O que se busca compreender, portanto, é, do ponto de vista da séria histórica, quais fatores potencialmente levaram ao incremento no recrutamento de indivíduos com carreiras prioritariamente jurídicas. Nesse sentido, os achados empíricos sugerem que tais períodos ocorreram especialmente como respostas ao fortalecimento institucional de tais tribunais. Ante um novo período de elevada proeminência dessas instituições, indivíduos reconhecidamente qualificados junto à comunidade jurídica passaram crescentemente a ser identificados como alternativas de legitimação de tais órgãos, seja em contextos de competição, seja em contextos de hegemonia política de determinados grupos.

\section{DESCRIÇÃO DO OBJETO}

$\mathrm{O}$ número de integrantes das cortes supremas dos dois países e suas formas de nomeação não 
se mantiveram inalteradas ao longo de tantas décadas. A prática de ampliar e reduzir o número de magistrados no STJi, STF e na USSC sempre foi freqüente. Ao passo que o tribunal brasileiro possuiu cinco números diferentes de integrantes ao longo de seus quase 180 anos de existência, a instituição estadunidense experimentou seis conformações diferentes em relação à quantidade de membros em seus mais de 200 anos de história. Quanto à estabilidade das regras de nomeação, todavia, a simetria entre os dois países não se mantém. Se, por um lado, a USSC apresentou uma única regra de investidura no cargo desde sua fundação em 1789, por outro lado, os diferentes órgãos de cúpula do poder Judiciário brasileiro já observaram três distintas formas de se nomear seus respectivos integrantes. A discriminação desses dados encontra-se na Tabela 1, abaixo, e merece pormenorização.

TABELA 1 - NÚMERO DE INTEGRANTES E REGRAS PARA NOMEAÇÃO NAS CORTES SUPREMAS DO BRASIL E DOS ESTADOS UNIDOS

\begin{tabular}{|c|c|c|}
\hline & BRASIL & ESTADOS UNIDOS \\
\hline \multirow[t]{7}{*}{ Número de integrantes } & 1829-1891 - 17 ministros & $1789-1807-6$ justices \\
\hline & $1891-1931$ - 15 ministros & $1807-1837-7$ justices \\
\hline & $1931-1965-11$ ministros & $1837-1863-9$ justices \\
\hline & $1965-1969-16$ ministros & 1863-1866 - 10 justices \\
\hline & 1969-atual- 11 ministros & 1866-1869- 7 justices \\
\hline & Média - 13,44 ministros & 1869-atual- 9 justices \\
\hline & & Média - 8,87 justices \\
\hline \multirow[t]{5}{*}{ Regras para nomeaçăo } & Três regras diferentes: & Uma única regra (1789. \\
\hline & - Regra do STJi (1829-1891): & atualidade): \\
\hline & $\begin{array}{l}\text { inđicaçãão péio imperadơor entre } \\
\text { os juizes letrados extraidos das } \\
\text { Reiaçōes por critério de } \\
\text { antigüudade e concessão de } \\
\text { título do Conselho; }\end{array}$ & 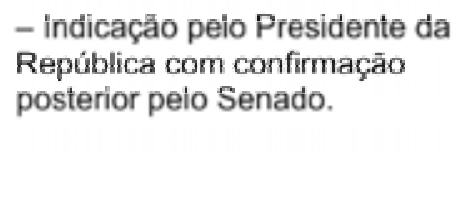 \\
\hline & $\begin{array}{l}\text { - Regra do STF (1891-1930; } \\
\text { 1934-1937; 1946-atualidade): } \\
\text { Indicaçăo pelo Presidente da } \\
\text { República com confirmação pelo } \\
\text { Senado; }\end{array}$ & \\
\hline & $\begin{array}{l}\text { - Regra do STF (1930-1934; } \\
\text { 1937-1945): Indicaçăo pelo } \\
\text { Presidente da República sem } \\
\text { confirmaçấo pelo Senado. }\end{array}$ & \\
\hline
\end{tabular}

FONTES: Epstein e Segal (2005) e Mello Filho (2007).

Primeiramente, observa-se que o órgão de cúpula da Justiça no Brasil sempre possuiu mais ministros do que a Suprema Corte dos EUA possuiu justices. O número máximo de integrantes da USSC não passou de 10 pelo curto período de três anos, mantendo-se em nove membros pela maior parte do tempo. Diferentemente, no Brasil, esse esteve por 106 anos entre os 15 e os 17 integrantes. Talvez por isso observe-se um número total de indivíduos nomeados a cada tribunal muito maior no Brasil do que nos EUA, como se verá adiante. Em segundo lugar, quanto à intensidade das alterações do número total de integrantes, no Brasil estas geralmente foram mais bruscas. Por outro lado, embora o número de integrantes da USSC tenha permanecido estável ao longo dos últimos 140 anos, várias propostas para a criação de novos cargos foram feitas, inclusive capitaneadas pelo próprio Presidente do país. O caso clássico é o court-packing plan proposto por Franklin D. Roosevelt em 1937, com o objetivo de forçar uma modificação nas posições na corte, 
que relutava em aceitar as medidas adotadas pelo governo em combate à Grande Depressão iniciada em 1929. Ainda que a proposta para incorporar novos membros ao tribunal não tenha sido implementada, o objetivo do governo foi atingido. Frente àquela ameaça, a corte modificou seu posicionamento e permitiu que o poder Executivo adotasse seus planos (CALDEIRA, 1987).

No que se refere às regras de nomeação dos integrantes dos tribunais dos dois países, ambas foram semelhantes pela maior parte do tempo. Nos EUA, desde que o tribunal foi estabelecido, assentou-se a prática de indicação dos justices pelo Presidente da República com posterior confirmação por dois terços do Senado, conforme consta do Article II, Section 2 da Constituição estadunidense. Método semelhante atualmente é empregado no Brasil, onde passou a existir a partir de 1891, quando a primeira Constituição republicana, inspirada diretamente na fórmula norte-americana, exigiu "notável saber e reputação" dos ministros como requisitos adicionais para a nomeação, que posteriormente, na Constituição de 1934, foram alterados para "notável saber jurídico e reputação ilibada", permanecendo assim desde então. Outra diferença menor fica por conta das maiorias requeridas para a confirmação pelo Senado. Ao passo que nos EUA se requer a concordância de pelo menos dois terços dos integrantes da Câmara Alta para a confirmação do nomeado, no Brasil se requer maioria absoluta. Apesar dessas dessemelhanças, é lícito afirmar que os procedimentos são muito semelhantes nos dois casos. Essa é a regra que tem se mantido desde a formação do STF, com apenas duas curtas interrupções durante os períodos de 1930-1934 e 1937-1945, quando a necessidade de confirmação pelo Senado foi suspensa, concedendo praticamente total discricionariedade ao Presidente da República nesse processo.

Antes do período republicano, a regra válida para o STJi durante todo o tempo de sua existência foi a indicação pelo Imperador entre os juízes letrados retirados das Relações - como eram chamados os atuais Tribunais de Justiça - com base em critério de antiguidade, como indicava o art. 163 da Constituição do Império. Além disso, para serem nomeados, os ministros deveriam receber o título do Conselho. Conforme se observa, a regra de escolha dos integrantes do STJi era bastante mais restritiva que aquela que veio a ser contemplada quando da instalação do
STF em 1891. No caso, a regra obrigava ao Imperador que o aludido recrutamento realizassese no interior da função judicial, excluindo inclusive outras carreiras ligadas ao exercício do Direito, como a advocacia. A regra ainda determinava que essa escolha fosse realizada por critério de antigüidade, o que tornava ainda mais circunscritas as opções. Em contraponto a esses critérios restritivos encontrava-se a necessidade do aludido título do Conselho para que fosse o escolhido efetivamente nomeado para o cargo de Ministro do STJi. Ainda sobre a regra de investidura, interessa observar que a escolha necessariamente recaía sobre os juízes letrados, isto é, portadores de diploma em Direito. Não se trata de uma observação óbvia. O fato dos ministros deverem ser aqueles considerados letrados restringia sobremaneira o leque de opções. Isso porque os juízes letrados eram aqueles que iniciaram suas carreiras ocupando o cargo de Juiz de Fora ou, posteriormente, de Juiz de Direito. Tratava-se de cargo ocupado por aqueles assim designados pelo Imperador e, na maior parte do tempo, sob controle direto do Ministério dos Negócios da Justiça. Contrariamente, os juízes de paz eram eleitos pelos grupos locais, fazendo-se freqüentemente presentes indivíduos não letrados, isto é, não portadores de diploma jurídico (VELLASCO, 2004). O fato dos ministros deverem ser recrutados dentre os letrados, portanto, encontrava-se em consonância com a estratégia de construção de uma elite nacional, desgarrada dos particularismos locais.

As três regras de investidura existentes no caso brasileiro parecem indicar três diferentes graus de circunscrição à vontade do chefe de Estado encarregado de promover a nomeação. Em primeiro lugar, como o mais restritivo àquela discricionariedade, tem-se o procedimento adotado durante o Império, que estabelecia critérios como seniority e recrutamento endógeno para que nomeação de integrantes à Suprema Corte brasileira de então. Em um espaço intermediário verifica-se a regra atual, copiada da realidade norteamericana, que tempera a indicação presidencial com critérios pouco objetivos de profissionalismo - o notável saber jurídico - e necessidade de confirmação senatorial. Por fim, como a regra mais discricionária encontra-se o procedimento adotado durante boa parte da Era Vargas, em que a existência de uma vaga e a vontade presidencial eram os únicos requisitos para proceder-se à 
nomeação, eis que desnecessária a confirmação pelo Senado. É importante levar em consideração essas variações quanto às regras de nomeação porque posteriormente examinar-se-ão seus efeitos sobre os graus de profissionalização observados entre os integrantes da Corte Suprema brasileira.

\section{EXAMINANDO AS DUAS REALIDADES}

Como forma de examinar os perfis de todos integrantes das cortes supremas do Brasil e dos EUA ao longo de suas histórias, foram consultados trabalhos acadêmicos e publicações institucionais que disponibilizassem tais informações. No caso brasileiro, as principais fontes foram os trabalhos de Lago (2001), Mello Filho (2007), Marenco dos Santos e Da Ros (2008), além do Anuário da Justiça, elaborado pela Fundação Armando Álvares Penteado (2007) e do próprio sítio mantido junto à rede mundial de computadores pelo $\mathrm{STF}^{10}$. Em relação aos justices da USSC, boa parte do material já se encontrava catalogada em banco de dados elaborado por Lee Epstein e outros pesquisadores, encontrando-se disponível na internet (EPSTEIN et alii, 2008). Esse foi complementado a partir do trabalho de Cushman (1995), sendo constituídas novas variáveis voltadas a responder questões de interesse deste artigo.

Semelhantemente, alguns critérios foram seguidos como forma de catalogar os dados consultados. Primeiramente, preferiu-se não incluir indivíduos rejeitados pelo Senado ou aqueles cujas indicações foram retiradas pela própria Presidência. Isso porque as primeiras (rejeições) são relativamente raras (cinco no Brasil e 12 nos EUA) e para as últimas (retirada da indicação) não há informações disponíveis para todo o horizonte temporal examinado, podendo constituir-se uma fonte de bias. Assim, a análise dos indivíduos indicados $e$ confirmados pelo Senado parece constituir-se em um indicador adequado dos perfis das elites judiciais integralmente consentidas pelas forças políticas do momento em cada país.

Quanto à USSC, convém observar que não se realizou diferenciação entre indicados a chief justice (Presidente do Tribunal) ou associate justice (Integrante da Corte). Um justice ocupou a corte em duas ocasiões distintas, Charles Evans Hughes, que chegou à corte em 1910 e saiu em 1916 para retornar ao tribunal em 1930 e deixá-lo em definitivo em 1941. Nesse caso, ele foi incluído duas vezes no banco de dados, uma vez que consubstancia duas nomeações distintas. No caso norte-americano são, portanto, 110 indivíduos os que ocuparam cargo na corte, mas que resultam em 111 casos para análise, entre os anos de 1789 e 2008.

Em relação ao caso brasileiro, também foram priorizados apenas os indivíduos que ocuparam cargos na corte de modo definitivo. Quando da transição do STJi ao STF em 1891, alguns ministros foram aproveitados ao novo tribunal. Nesses casos, como esses indivíduos não deixaram a corte para exercer outras atividades, sendo simplesmente reempossados no novo órgão, eles não foram computados duas vezes, mas apenas uma única vez ${ }^{11}$. Exatamente como ocorreu com o justice Hughes, o Ministro José Francisco Rezek foi nomeado duas vezes para o STF, primeiramente em 1983, renunciando ao cargo na corte em 1990, para a ela retornar em 1992, deixando-a em definitivo em 1997. Por isso, seu caso fora computado duas vezes, uma a cada nomeação. A síntese das informações que constituem o universo de casos analisados encontra-se na Tabela 2, abaixo.

TABELA 2 - DADOS GERAIS SOBRE OS INTEGRANTES DAS CORTES SUPREMAS DO BRASIL E DOS ESTADOS UNIDOS

\begin{tabular}{|l|c|c|}
\hline & BRASIL & ESTADOS UNIDOS \\
\hline Tempo total (em anos) & 179 & 219 \\
Casos sob análise (total de & 274 & 111 \\
nomeaçōes) & 273 & 110 \\
Individuos sob análise & 1,53 & 0,51 \\
Média anual de nomeaçōes & & \\
\hline
\end{tabular}

FONTE: O autor, a partir de Lago (2001), Fundação Armando Álvares Penteado (2007), Mello Filho (2007), Marenco dos Santos e Da Ros (2008), Brasil (2011) e Epistein (2011).

10 O sítio do Supremo Tribunal Federal mantém

informações sobre as biografias de seus ministros. Cf. Brasil (2011). 
De início, observa-se uma diferença bastante acentuada entre os dois tribunais especialmente quanto ao último quesito, média anual de nomeações. A diferença é de mais de três vezes entre uma corte e outra, sugerindo maior freqüência de indicações no Brasil do que nos Estados Unidos. Algumas hipóteses podem contribuir para explicar essa diferença. Em primeiro lugar, devese mencionar o número total de integrantes das cortes. Conforme observado, o tribunal brasileiro hoje apresenta 11 membros, já apresentou 15 e 16 integrantes, respectivamente, e possuiu 17 membros durante o longo período durante o Império (1829-1891). Diferentemente, a composição da corte estadunidense manteve-se estável durante muito tempo, adotando os nove membros que hoje a caracterizam ainda no século XIX e sempre possuindo menos integrantes do que a corte brasileira. Isso significa que a faculdade conferida a um Presidente de nomear um novo membro à corte é mais freqüente no Brasil, mas que seu efeito sobre a composição do tribunal não é tão elevado quanto aquele apresentado por uma indicação realizada pelo Presidente norte-americano. Em segundo lugar, as regras de saída de integrantes do tribunal são diferentes. Ao passo que os ministros do STF, desde a Constituição de 1934, são obrigados a aposentarem-se quando completam determinada idade - aos 75 na Constituição de 1934, aos 68 em 1937 e aos 70 desde 1946, seguindo a regra de aposentadoria compulsória que vale para todo funcionalismo público - os justices da USSC permanecem no tribunal até o momento em que decidem aposentar-se, não havendo idade-limite para tanto. Isso dificulta o surgimento de novas vagas, reduzindo a periodicidade das nomeações (MCGUIRE, 2005)

\footnotetext{
11 Como foi dada a tais ministros a opção por permanecerem ou retirarem-se do tribunal, não se tratam de novas nomeações, podendo deduzir-se que a elite política de
}

Em terceiro lugar, há uma importante diferença quanto à estabilidade política dos dois países ao longo da história, com possíveis reflexos sobre a composição das respectivas cortes supremas. Ao passo que os episódios de court-packing nos EUA apenas no século XIX levaram a alguma alteração na composição da corte, no Brasil esses episódios foram mais freqüentes e conduziram a mudanças mais abrutpas quanto ao número total de integrantes da corte. Não raramente integrantes do STF foram aposentados compulsoriamente ao longo da história, dando vazão à indicação de novos ministros afeitos ao alinhamento político preconizado pelos sucessivos presidentes e regimes políticos instalados. Alguns episódios, como os impasses gerados nos momentos iniciais de mudanças políticas turbulentas, como a proclamação da República em 1889, a Revolução de 1930 e o Golpe Militar de 1964, são claros nesse sentido. Uma última hipótese explicativa leva em consideração as regras de acesso aos cargos, especialmente aquela que existiu no Brasil durante o Império. Como os ministros do STJi eram retirados das Relações com base no critério de antiguidade, a rotatividade dos membros elevou-se sobremaneira com passar dos tempos, visto que os titulares adoeciam, aposentavam-se ou simplesmente faleciam pouco tempo depois de chegar à Corte Suprema. Isso atingiu níveis críticos como, por exemplo, em 1886 , quando nove novos ministros foram indicados ao tribunal, e sete deles no ano seguinte, levando a uma renovação quase completa do tribunal em apenas dois anos. Somente no intervalo de 20 anos entre 1880 e 1900 foram nomeados 65 novos integrantes para o tribunal. O gráfico abaixo expõe essas informações. Convém observar, entretanto, que nesse período verifica-se a conjunção de dois fatores propícios para alterações na composição da corte - o efeito da regra de seniority no STJi e a implantação do regime republicano. 
GRÁFICO 1 -NÚMERO TOTAL DE INTEGRANTES NOMEADOS PARA CADA TRIBUNAL

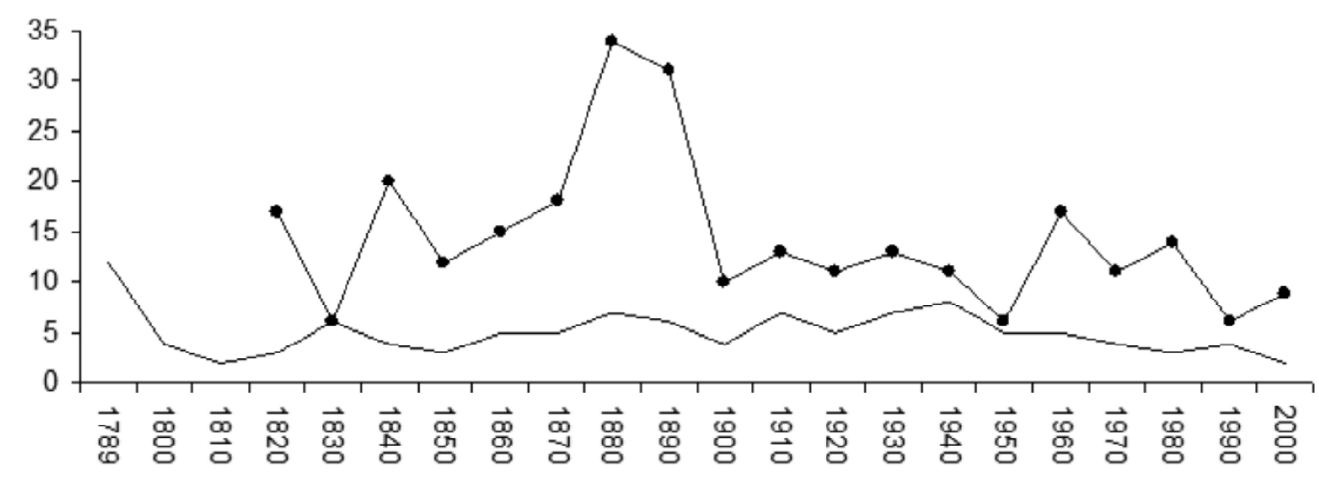

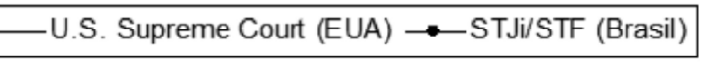

FONTE: O autor, a partir de Lago (2001), Fundação Armando Álvares Penteado (2007), Mello Filho (2007), Marenco dos Santos e Da Ros (2008), Brasil (2011) e Epistein (2011).

Se o efeito da regra de investidura do STJi explica a sensível elevação de magistrados nomeados durante parte do século XIX, a hipótese relativa aos períodos de instabilidade política no Brasil parece efetivamente confirmar-se quando levamos em consideração os chefes de Estado que mais nomearam integrantes para os órgãos de cúpula da Justiça brasileira e, em menor medida, nos EUA. Como expõe a Tabela 3, além de líderes que ficaram muito tempo à frente do governo (como Dom Pedro II e Getúlio Vargas), os chefes de Estado que mais nomearam integrantes para a Suprema Corte do Brasil estão quase sempre associados a períodos de elevada instabilidade política, como a independência do país e conseqüente instalação de novos tribunais (Dom Pedro I), a Proclamação da República, sua consolidação e instalação da nova Corte Suprema (Deodoro da Fonseca e Floriano Peixoto), o início do regime militar (Castello Branco) e sua posterior transição para a democracia (João Figueiredo), além da própria Era Vargas.

TABELA 3 - CHEFES DE ESTADO QUE MAIS NOMEARAM INTEGRANTES PARAAS CORTES SUPREMAS DE BRASIL E ESTADOS UNIDOS

\begin{tabular}{|l|l|}
\hline BRASIL & ESTADOS UNIDOS \\
\hline Dom Pedro II - $98(35,3 \%)$ & George Washington $-10(9 \%)$ \\
Getúlio Vargas $-21(7,7 \%)$ & Franklin D. Roosevelt $-8(7,2 \%)$ \\
Dom Pedro I- $17(6,2 \%)$ & Andrew Jackson $-6(5,4 \%)$ \\
Deodoro da Fonseca $-16(5,8 \%)$ & Abraham Lincoln $-5(4,5 \%)$ \\
Floriano Peixoto $-14(5,1 \%)$ & William H. Taft $-5(4,5 \%)$ \\
Joăo Figueiredo $-9(3,3 \%)$ & Dwight D. Eisenhower $-5(4,5 \%)$ \\
Castello Branco $-8(2,9 \%)$ & \\
\hline
\end{tabular}

FONTE: O autor, a partir de Lago (2001), Fundação Armando Álvares Penteado (2007), Mello Filho (2007), Marenco dos Santos e Da Ros (2008), Brasil (2011) e Epistein (2011).

A intensidade das transformações políticas também parece explicar os presidentes que mais nomearam justices nos EUA, embora com menor acuidade. Os nomes de George Washington, Franklin D. Roosevelt e Abraham Lincoln, ligados a eventos como a independência do país e instalação da Corte Suprema, a emergência do welfare state e a Guerra Civil, enquadram-se perfeitamente nesse perfil, embora os nomes de Andrew Jackson, William Taft e Dwight Eisenhower não se coadunem com esse padrão. 
Passando ao exame do objeto desse artigo, a seção abaixo examina os perfis de carreira dos indivíduos recrutados para a Corte Suprema dos dois países no que se refere aos indicadores de sua profissionalização, examinando a circulação por arenas políticas, coercitivas ou exclusivamente jurídicas.

\section{JUÍZES PROFISSIONAIS?}

Um dos principais proxies para identificar juristas profissionais entre os nomeados é apontar aqueles que exerceram apenas profissões jurídicas antes de ingressar no cargo. Nesse sentido, foram consideradas carreiras exclusivamente jurídicas aquelas que não envolviam a passagem por cargos tipicamente políticos, junto aos poderes Executivo e Legislativo, ou tradicionalmente voltados à administração de atividade coercitiva do Estado, como aqueles em postos superiores de corporações militares ou policiais ${ }^{12}$. O Gráfico 2, exposto abaixo, discrimina esses padrões ao longo das histórias políticas de Brasil e EUA.

Algumas leituras podem ser realizadas a partir

\section{GRÁFICO 2-CARREIRA EXCLUSIVAMENTE JURÍDICA}

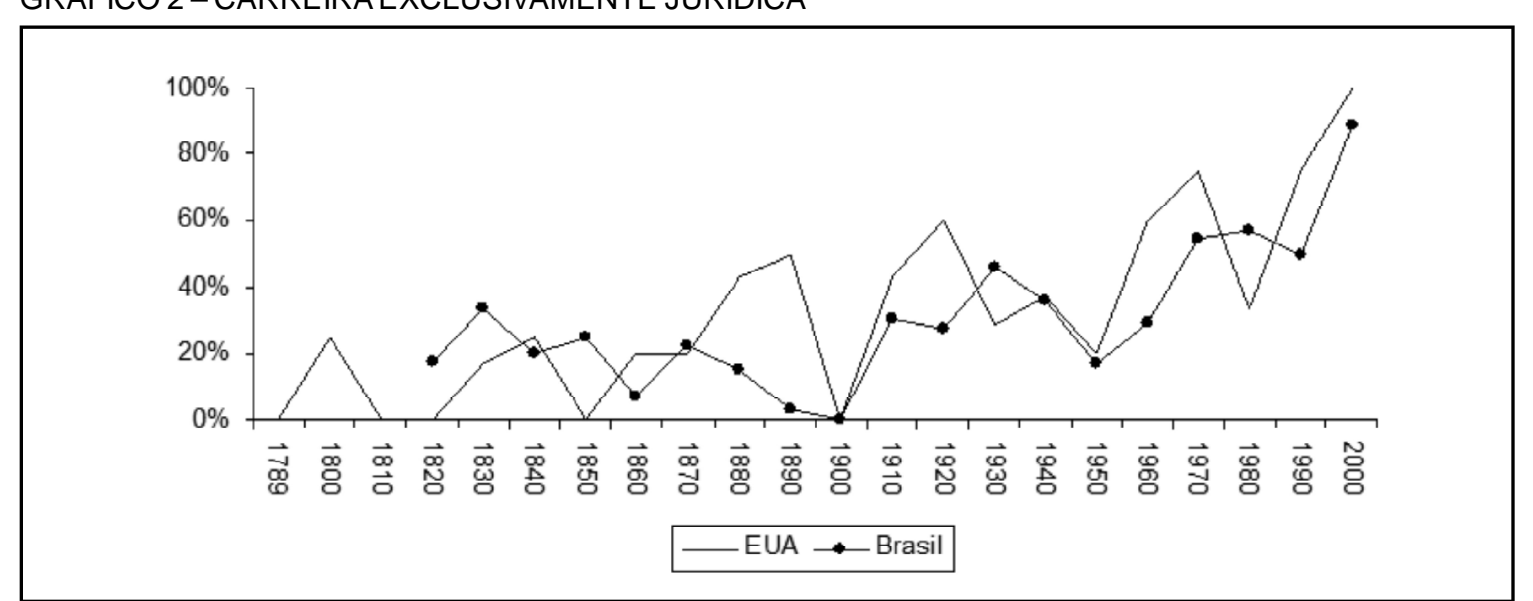

FONTE: O autor, a partir de Lago (2001), Fundação Armando Álvares Penteado (2007), Mello Filho (2007), Marenco dos Santos e Da Ros (2008), Brasil (2011) e Epistein (2011).

dos dados acima. Uma primeira, mais geral, observa que o recrutamento de juristas profissionais é mais exceção do que regra nos dois casos, apesar de importantes variações históricas. Entre os 274 nomeados ao STJi-STF, apenas 72 indivíduos - $26,3 \%$ do total - apresentaram carreiras exclusivamente jurídicas antes de ingressar na corte. Esse valor é semelhante ao encontrado na realidade norte-americana, embora levemente superior nos EUA. Entre os 111 nomeados para a USSC, 35 justices $-31,5 \%$ do total - não haviam ocupado outros cargos que não aqueles próprios do universo jurídico antes de ingressar no tribunal.

Essa supremacia de indivíduos não vinculados exclusivamente às profissões jurídicas, todavia, não é linear. Como se observa, em alguns momentos, há freqüência maior de indivíduos retirados apenas dessas carreiras, ao passo que em outros há efetivamente o predomínio de recrutados com experiência política e/ou coercitiva. Há aqui, portanto, uma oportunidade para discutirem-se os contextos históricos que propiciam incremento ou decréscimo no recrutamento de juristas profissionais para as cortes supremas das duas realidades, ensejando uma discussão sobre os fundamentos políticos do profissionalismo.

Quanto ao caso brasileiro, observa-se acima alguns picos importantes de ascensão do recrutamento de indivíduos profissionais exclusivamente da área para o órgão de cúpula da

12 Nesse sentido, cargos de natureza meramente burocrática, ou administrativa, não foram considerados relevantes para essa classificação. Isso porque geralmente eles, quando presentes, são ocupados pelos justices norteamericanos e pelos ministros brasileiros apenas no início de suas carreiras, por pouco tempo, e como uma forma de ascenderem a outros cargos de natureza distinta, jurídica, política ou coercitiva. 
Justiça brasileira. O primeiro faz-se presente já em 1830, durante a Regência, mas segue-se a ele uma longa e gradativa queda até o final do século XIX, quando atinge seu nível mínimo na década de 1900. Imediatamente após, na década de 1910, observa-se um importante salto em direção à profissionalização da elite judicial brasileira, aproximando-se da metade do total de indivíduos nomeados para a corte pela primeira vez na década de 1930 , quando atinge inéditos $46,1 \%$ de ministros sem qualquer outra vinculação que não às carreiras tradicionais do mundo jurídico. Desse momento até a década de 1950, observa-se uma trajetória de queda, que se reverte a partir dos anos 1960 e particularmente da década de 1970, ultrapassando a marca dos $50 \%$ pela primeira vez, não retornando a um patamar inferior desde então. Entre 2000 e 2008, quando se encerrou a coleta desses dados, atinge-se o período em que mais juristas de carreira foram nomeados para a corte, totalizando $88,8 \%$ ministros com carreiras exclusivamente jurídicas recrutados.

Quanto à trajetória dos justices recrutados para a Suprema Corte dos Estados Unidos, observa-se algumas semelhanças. Como ocorre no congênere brasileiro, os níveis de profissionalismo mantêmse fundamentalmente baixos ao longo da maior parte do século XIX, aproximando-se dos 50\% apenas nas décadas de 1880-1890. Observa-se uma interrupção desta tendência na década de 1900, mas volta-se a crescer na década seguinte, atingindo-se quase $60 \%$ nos anos 1920 . Doravante, verifica-se uma queda continuada até a década de 1950 para observar-se na década seguinte um crescimento significativo e praticamente continuado até a década atual, com interrupção apenas nos anos 1980.

Algumas constatações importantes emergem desses dados e, ao que parece, as hipóteses explicativas para as mudanças históricas desdobram-se em dois sentidos. O primeiro é o que parece ser uma condição necessária, mas não suficiente, para a nomeação de indivíduos profissionais do mundo jurídico para esses tribunais. No caso, trata-se da própria relevância política dessas Cortes Supremas. Se esta é reduzida ou praticamente inexistente, o profissionalismo dificilmente parece ser estimulado. Como se sabe, o fortalecimento institucional de tais cortes é relativamente recente nos dois países, sendo um fenômeno basicamente do final do século XIX nos dois casos. No Brasil, foi nesse período que o
STF passou a existir como órgão capaz de controlar a constitucionalidade das leis, função que seu congênere anterior, o STJi, não exercia, visto que tal função era atribuída ao Conselho de Estado durante o período imperial. Nos EUA, embora a Suprema Corte formalmente tenha tido essa faculdade desde 1803, somente a partir do final do século XIX começou a exercê-la com freqüência. Durante os 100 anos entre 1789 e 1889, aquele tribunal declarou inconstitucionais apenas 18 leis federais, o que representa somente $12,8 \%$ do total de leis declaradas inconstitucionais pela corte ao longo de toda sua história (KEITH, 2007). O segundo sentido, entretanto, é menos imediato e apresenta dois contextos distintos que parecem contribuir para o incremento da ocorrência de tal fenômeno.

O primeiro deles é aquele em que se verifica a hegemonia de determinado grupo ou conjunto de idéias na condução da atividade política. Tal hipótese é exemplificada pela afirmação de Cornell Calyton: "During a period where ideological and cultural consensus is strong it is natural to think of law not in political but in technical terms"13 (CALYTON, 1999, p. 19). Pensar a prática jurídica em termos estritamente técnicos e apolíticos, dando vazão à nomeação de indivíduos com essas características, pode auxiliar na explicação para os incrementos no recrutamento de indivíduos profissionalizados para os órgãos de cúpula do poder Judiciário dos dois países. A lógica do recrutamento de juristas profissionais para a Corte Suprema integra-se, portanto, a uma lógica mais ampla de inexistência de controvérsia com relação a determinado conjunto de valores e idéias. No caso, certos posicionamentos são tão consensuais - pelo uso implícito da força ou pela existência de crenças compartilhadas - que se torna virtualmente desnecessário recrutar indivíduos politicamente alinhados ao governo ou ao regime para assegurar-se uma corte leal às práticas políticas existentes. Cria-se uma forma de legitimação técnica em que a própria profissão passa a acompanhar essa lógica e formar seus quadros dentro dessa ideologia comum, compreendida como técnica.

\footnotetext{
13 "Durante um período em que o consenso ideológico e cultural é forte, é natural pensar na lei não em termos políticos, mas técnicos". (N.R.).
} 
Nos EUA, trata-se, por exemplo, do período de supremacia republicana do final do século XIX e início do século $X X$, que se estendeu até princípios da década de 1930, quando os embates pela aprovação do New Deal e sua recepção pela Suprema Corte fizeram-se presentes. Não à toa o período ficou conhecido como "governo dos juízes", época em que o poder Judiciário federal bench e a Suprema Corte foram poderosamente insulados das arenas político-representativas com o propósito de nacionalizar a política econômica do período posterior à Guerra Civil (GILLMAN, 2002). Esse parece ser também o caso de alguns períodos históricos do Brasil, especialmente aqueles de natureza autoritária. Durante os anos 1930, houve relevante incremento na profissionalização dos magistrados, o mesmo ocorrendo durante o regime militar, especialmente durante os anos 1970 e 1980 . Essa tendência de profissionalização coaduna-se com o que se escrevia na época: "Desde então [1968], sobretudo com a edição dos Atos [Institucionais] ns. 5 e 6, cessaram os conflitos, e o Poder Executivo-Revolucionário passou a ter no Supremo um órgão administrativamente saudável, tecnicamente ágil, [...] mas politicamente morto" (VALE, 1976, p. 166).

Diferentemente, o segundo contexto parece ocorrer em condições diametralmente opostas. Ele estabelece-se em um ambiente de maior pluralidade de centros de poder, decorrendo diretamente de momentos em que se verifica o fortalecimento institucional das cortes supremas em questão e de sua atuação frente a questões polêmicas e politicamente relevantes. Trata-se, na realidade, de um argumento conhecido pelos cientistas sociais que trabalham com a política de preenchimento de cargos em outros contextos e instituições (LOUREIRO, 1997; D'ARAÚJO, 2007; OLIVIERI, 2007; CARVALHO, 2008). Nessa linha, o custo político de promover-se a nomeação de aliados políticos para determinados órgãos em contextos de competição política elevase em função da controvérsia trazida pela importância dos cargos, pela visibilidade das instituições e pela própria sensibilidade de determinadas áreas, como recentemente observase na área econômica no Brasil. Nesses contextos, aqueles que realizam a nomeação recorreriam a candidatos reconhecidos por seu mérito profissional como estratégia para evitar críticas de oponentes, de aliados e dos próprios profissionais da área.
No caso, verificou-se o incremento do recrutamento endógeno às carreiras jurídicas no Brasil na década de 1910, justamente após uma série de embates entre o recém-instalado STF, que inaugurara poucos anos antes seus poderes de judicial review, e os primeiros governos do regime republicano, especialmente com relação à aplicação da chamada "doutrina brasileira do habeas-corpus" (KOERNER, 1999). Em virtude dos impasses gerados pela atuação da corte no período, exercendo pela primeira vez a capacidade de rever a constitucionalidade das leis e libertando presos políticos por meio da aplicação de tal doutrina jurídica, a relevância política conquistada pelo tribunal parece ter transformado a nomeação de seus futuros ministros em um processo crescentemente controverso. Nesse contexto, é razoável supor que indicar mais juristas profissionais para os cargos integra-se uma lógica de evitar controvérsias quanto às nomeações frente a temas como esses. O mesmo parece ocorrer com a intensa nomeação de juristas profissionais nos anos 2000, resultado da importância que o STF adquiriu como resultado da Constituição de 1988, que o colocou entre os mais poderosos tribunais com jurisdição constitucional do mundo (ARANTES, 1997; VIANNA et alii, 1999; TAYLOR, 2008). Essa interpretação é corroborada por recente estudo sobre as aprovações de autoridades pelo Senado no Brasil. Lemos e Llanos (2007) apostam em uma hipótese de acomodação para explicar a rapidez com são aprovados nomes indicados para órgãos como o STF. Por serem fundamentalmente não controversos, isto é, acomodados previamente às preferências dos senadores, eles não enfrentariam resistência na Câmara Alta brasileira e seriam rapidamente ratificados. Na palavra das autoras: "Esses extremos talvez apontem uma hipótese de acomodação no Brasil: quanto aos casos mais rápidos, o presidente preveria a reação do Congresso e enviaria um nome que pudesse obter o apoio necessário. Isso é verdade tanto para os cargos voltados para o mercado como para os cargos de alto escalão no Judiciário, especialmente aqueles do Supremo Tribunal Federal, que levam cerca de dezenove dias para serem aprovados" (idem, p. 123).

Levando-se em conta os achados desta pesquisa, pode-se supor que esse consenso em torno dos indicados ao tribunal é em grande medida fruto do reconhecimento do mérito desses 
nomeados. Por sua vez, no que se refere à realidade norte-americana, a tendência parece ser o paulatino incremento do recrutamento endógeno às carreiras jurídicas como fruto da importância política da corte quando esta passou a capitanear a chamada rights revolution do país, durante as décadas de 1950 e 1960, evolvendo interpretações do texto constitucional em matérias politicamente sensíveis, como as políticas de integração racial do país (EPP, 1998). Ademais, os anos 1960 inauguraram aquele que provavelmente é o período de mais intenso ativismo daquele tribunal, traduzindo-se em 67 leis federais declaradas inconstitucionais pela USSC durante os 41 anos entre 1960 a 2001 , o equivalente $45,9 \%$ do total de leis declaradas inconstitucionais pela corte desde sua fundação (KEITH, 2007). Em função disso inclusive tem sugerido que o tribunal recentemente tem atuado mais em torno de seus próprios interesses e menos de acordo com as linhas ideológicas dos presidentes que os nomearam os justices, como se interpreta tradicionalmente (KECK, 2007).

Todavia, importa salientar que o processo de appointment dos membros da USSC é sabidamente orientado de maneira partidária e ideológica - presidentes republicanos tendem a indicar justices conservadores e presidentes democratas buscam nomear indivíduos liberais para a corte. Tanto isso é verdadeiro que praticamente todos os indicados para a USSC eram filiados a partidos políticos antes de nomeação. Das 111 nomeações, em apenas um caso, do justice Felix Frankfurter, o indicado era independente, não filiado a nenhum partido político. Isso, entretanto, não impediu a nomeação de justices filiados a partidos diferentes daquele do próprio Presidente da República, mesmo que esses sejam casos minoritários, totalizando apenas cerca de $10 \%$ do universo de análise, como já apontam os pesquisadores há muito tempo (NAGEL, 1961). Apesar desses elementos sugerindo a presença de vínculos partidários e ideológicos entre os integrantes da Suprema Corte dos EUA, o avanço do recrutamento de indivíduos profissionalizados e preponderantemente vinculados às carreiras típicas do universo jurídico é um fenômeno inegável especialmente a partir dos anos 1960. O mérito individual dos indicados tem sido empregado justamente como forma de dissuadir senadores de ideologias e partidos opostos a aceitarem as nomeações, exatamente como ocorre no Brasil. Conforme argumentam dois autores em conhecido trabalho sobre a importância da qualificação profissional dos justices no processo de confirmação junto ao Senado dos EUA: "Despite their political outlooks, they received the highest possible merit rating, and senators, even those on the other side of the ideological fence, may have found difficult to justify voting against them"14 (EPSTEIN \& SEGAL, 2005, p. 103).

Sabe-se, ademais, que a partir da década de 1960 passou a viger nos Estados Unidos uma regra informal demandando o recrutamento endógeno à carreira judicial, a chamada norm of prior judicial experience (EPSTEIN, KNIGHT \& MARTIN, 2003). A referida norma aparentemente teria surgido como decorrência da decisão no famoso caso Brown v. Board of Education, em 1954. As críticas de parlamentares contrários à decisão teriam gradativamente conduzido a um entendimento de acordo com o qual, como forma de evitar decisões controversas como essa, seria urgente indicar para a corte "[...] men who would base their decisions upon law, not sociology" 15 (Schmidhauser apud EPSTEIN, KNIGHT \& MARTIN, 2003, p. 910). O efeito foi o incremento das nomeações de indivíduos com carreiras exclusivamente jurídicas e especialmente dos magistrados junto ao poder Judiciário federal do país, que passou a ser a principal fonte de recrutamento para os integrantes da USSC desde então. A maioria dos justices que ingressaram no tribunal a partir da década de 1960 eram integrantes daquele segmento do poder Judiciário no exato momento em que foram indicados para a Corte Suprema, perfazendo $61,1 \%$ desde então e nada menos de $76,9 \%$ do total a partir da década de 1970 .

Como o processo de preenchimento das vagas das instâncias inferiores da hierarquia judicial federal norte-americana realiza-se da mesma forma adotada para os justices da USSC, o que se tem priorizado é portanto a indicação de indivíduos que já foram previamente aprovados pelo Senado, ainda que para outros cargos. Como se observa no

\footnotetext{
14 “Apesar de suas orientações políticas, eles receberam a maior avaliação por mérito possível, e senadores, mesmo aqueles do outro lado da cerca ideológica, podem ter achado difícil justificar o voto contra eles".

15 "Homens que baseariam suas decisões na lei, não na Sociologia” (N.R.).
} 
Gráfico 3, abaixo, a tendência de recrutamento de juízes do federal bench é clara a partir da década de 1960. Mesmo que menos intenso que o atual, o outro pico de nomeações entre os juízes federais para a Suprema Corte coincide curiosamente com o outro período em que houve ascensão do recrutamento de indivíduos profissionais da área para o tribunal, no período de supremacia republicana entre 1880 e 1920, como visto anteriormente. Paralelamente ao padrão que se iniciou nos anos 1960, essa crescente presença de justices que antes eram juízes do poder Judiciário federal nos EUA tem sido acompanhada pelo recrutamento de indivíduos que antes eram professores universitários, como se confere no mesmo gráfico a seguir, priorizando-se também a indicação de indivíduos com reputação de elevada qualificação profissional na área, como já apontado em outros estudos (EPSTEIN \& SEGAL, 2005; EPSTEIN et alii, 2005).

GRÁFICO 3 - INDICADORES DE PROFISSIONALIZAÇÃO ENTRE OS INTEGRANTES DA SUPREMA CORTE DOS EUA

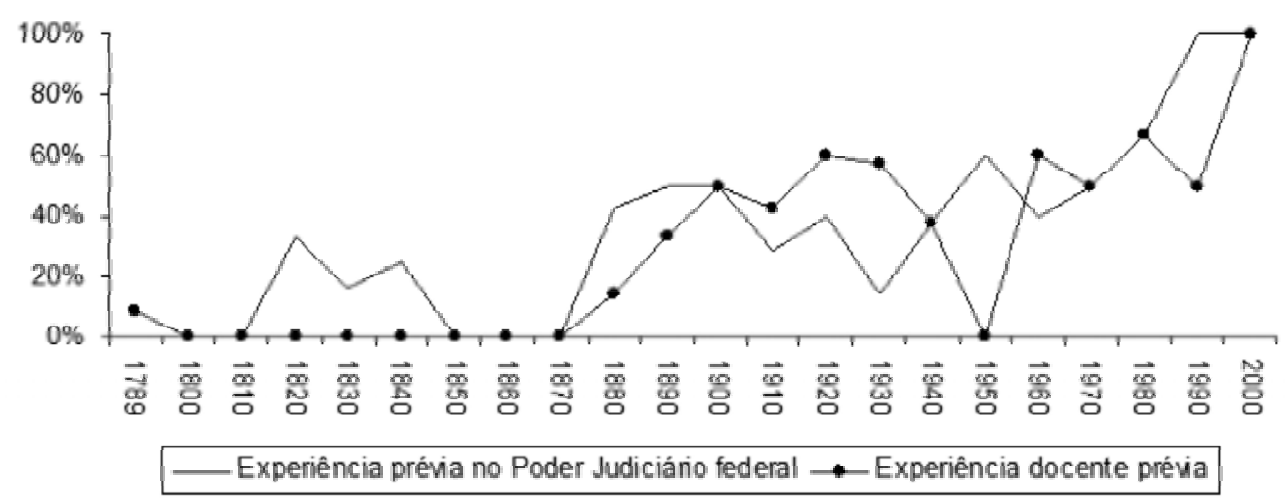

FONTE: O autor, a partir de Lago (2001), Fundação Armando Álvares Penteado (2007), Mello Filho (2007), Marenco dos Santos e Da Ros (2008), Brasil (2011) e Epistein (2011).

O Brasil, por sua vez, vem seguindo recentemente um padrão de recrutamento que enfatiza a expertise e o recrutamento endógeno às carreiras jurídicas, mas que condena o recrutamento endógeno exclusivo à carreira judicial. É como se, no Brasil, o que se buscasse fosse constituir a legitimidade das nomeações junto a todas as profissões do mundo do Direito, incluindo advogados, procuradores, professores universitários e magistrados, especialmente entre as nomeações recentes. Essa experiência diferencia o caso brasileiro da tendência internacional, em que geralmente prioriza-se a experiência judicial prévia como requisito. Outros parecem ser os requisitos para a indicação à Corte Suprema no Brasil, portanto. Um primeiro que parece ter se assentado ainda durante a primeira expansão do número de profissionais no tribunal é o exercício de atividade docente, cujo crescimento vendo sendo praticamente constante desde o início do século XX, atingindo-se o nível máximo na década de 2000, como se confere abaixo. 
GRÁFICO 4 - INDICADORES DE PROFISSIONALIZAÇÃO ENTRE OS INTEGRANTES DO STJI-STF NO BRASIL

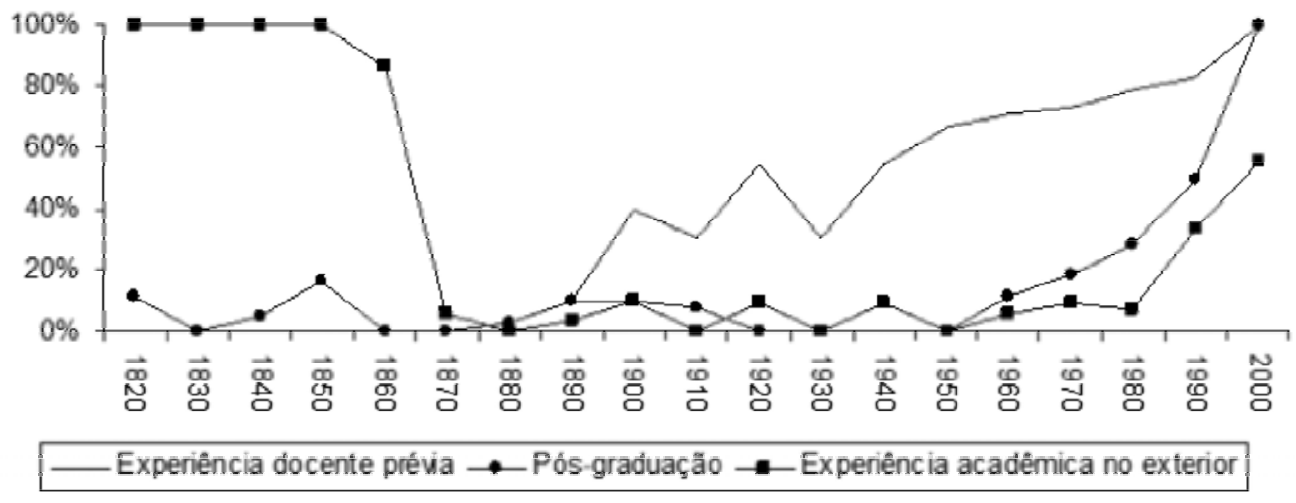

FONTE: O autor, a partir de Lago (2001), Fundação Armando Álvares Penteado (2007), Mello Filho (2007), Marenco dos Santos e Da Ros (2008), Brasil (2011) e Epistein (2011).

Coerente com a tendência recente de profissionalização, observa-se que a realização de cursos de pós-graduação vem se constituindo um elemento importante nesse sentido, expandindose vagarosamente a partir dos anos 1960 e alcançando níveis elevados nas décadas de 1990 e, especialmente, 2000, quando todos os nomeados possuíam título de Doutor em Direito antes de ingressar no tribunal ${ }^{16}$. Outro elemento que vem recentemente ganhando espaço nesse mesmo sentido no Brasil é a experiência acadêmica no exterior. Esse tipo de formação, que já foi fundamental para a elite política brasileira durante boa parte do século XIX (CARVALHO, 1980), e que representa o pico de 1820 a 1870 no gráfico anterior, constituindo a Faculdade de Direito da Universidade de Coimbra seu símbolo mais imediato, hoje parece coadunar-se perfeitamente com a tendência

16 De 1980 até 2008, entre os 29 ministros nomeados para a Corte, onze haviam concluído curso de Doutorado antes da posse, dois o Mestrado e dois a Especialização. A principal instituição para a realização desses estudos é a Universidade de São Paulo, que formou quatro doutores e um Mestre para a corte, seguida pelas Universidades de Paris, que formaram três doutores para o tribunal. É importante ressaltar que a realização de pós-graduação não é um indicador adequado de profissionalização entre os justices da U.S. Supreme Court porque o curso universitário em Direito nos Estados Unidos já é um graduate study, sendo o título obtido de tal formação Juris Doctor ou simplesmente J. D. - suficiente para o exercício da docência em nível superior. Por isso preferiuse incluir essa variável apenas no caso brasileiro, mas não no norte-americano. de profissionalização da elite judicial do país e de grande número de juristas brasileiros em geral (ENGELMANN, 2008). A partir dos anos $1990 \mathrm{e}$ com mais força a partir da década atual, tem-se observado que os futuros ministros do STF vêm crescentemente circulando em instituições estrangeiras como professores e pesquisadores visitantes, quando não realizado seus estudos de pós-graduação diretamente fora do Brasil ${ }^{17}$.

A crescente profissionalização dos integrantes das cortes supremas do Brasil e dos Estados Unidos parece estar ligada, portanto, a dois fatores. Um deles é a sua diferenciação com relação às carreiras políticas; o outro ocorre frente aos cargos voltados à administração da atividade coercitiva do Estado. Expor brevemente como tem ocorrido a diferenciação profissional dos ministros do STJi-STF e dos justices da USSC em relação a tais carreiras é o que se passa a fazer.

Começando pela circulação dos futuros magistrados de cortes supremas em cargos de natureza política, verifica-se que tanto no Brasil quanto nos EUA, há presença marcante de indivíduos que passaram por postos junto aos

17 Dos 15 ministros nomeados a partir de 1990, sete deles, o equivalente a $46,6 \%$ do total, possuem alguma experiência de natureza acadêmica fora do Brasil. Os principais destinos são Estados Unidos (5) e França (3), além de Alemanha (1) e Reino Unido (1). A soma dos países não é igual ao número de ministros que tiveram esse tipo de experiência porque alguns deles passaram por mais de um país para realizar seus estudos. 
poderes Executivo e Legislativo. No caso brasileiro, $59,8 \%$ do total de indivíduos passaram por cargos dessa natureza, somando $63,9 \%$ nos Estados Unidos. Conforme se observa no Gráfico 5, abaixo, o recrutamento de indivíduos com experiência política prévia para os órgãos vem diminuindo gradativa e continuadamente, embora tenha sido o principal tipo de experiência paralelamente àquela jurídica entre os integrantes dos órgãos de cúpula da Justiça dos dois países. Essa semelhança dos dados, entretanto, esconde algumas diferenças importantes entre as duas realidades. Quando se considera a passagem por cargos eletivos de natureza legislativa (em nível local, estadual ou nacional), observa-se que esta constituiu a principal fonte de circulação política nos EUA. Ao todo, 51,4\% dos justices da USSC passaram por esse tipo de cargo antes de ingressar na Corte Suprema do país, contra 33,3\% daqueles que passaram por cargos vinculados ao poder Executivo. Contrariamente, no Brasil a ênfase tem sido a passagem por cargos não eletivos junto ao poder Executivo, como ministros e Secretários de Estado, representando 45,3\% do total. Esse percentual, entretanto, não se afasta muito daquele de $41,6 \%$, que indica o universo de indivíduos que passaram por postos legislativos no Brasil antes de ingressar na Corte Suprema.

\section{GRÁFICO 5-EXPERIÊNCIA POLÍTICA PRÉVIA}

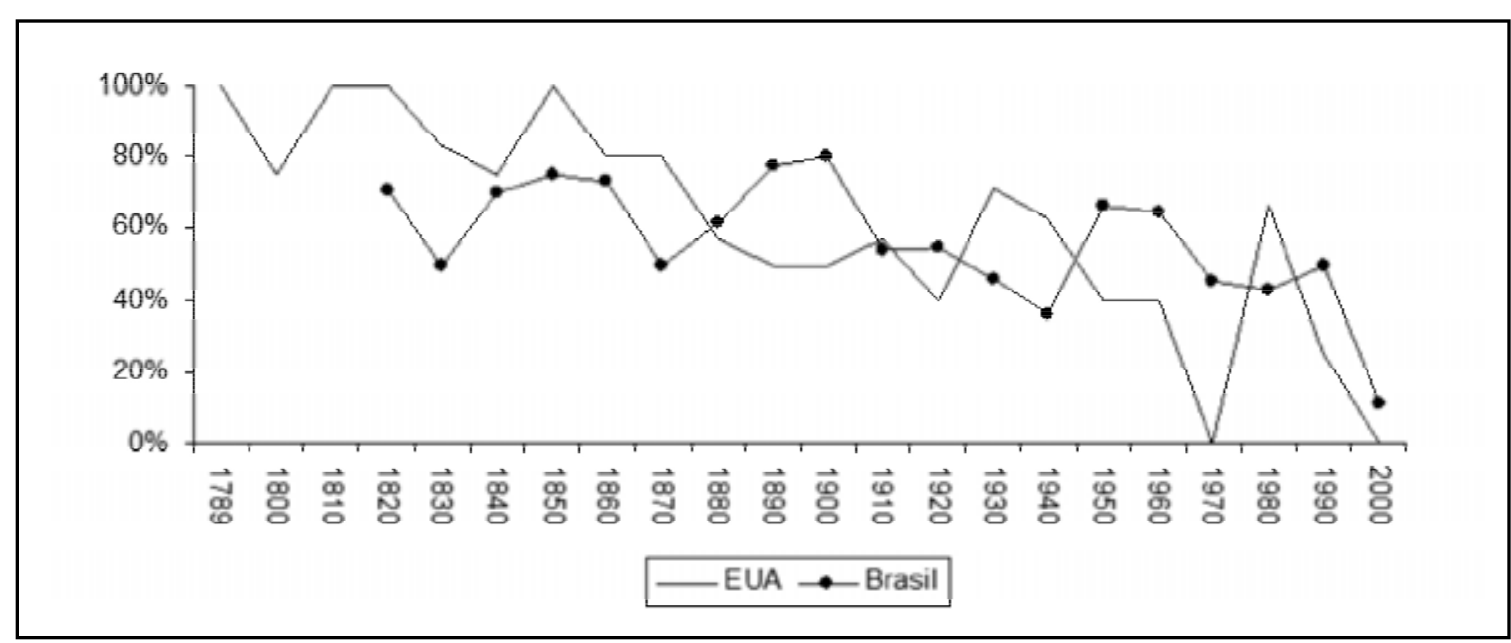

FONTE: O autor, a partir de Lago (2001), Fundação Armando Álvares Penteado (2007), Mello Filho (2007), Marenco dos Santos e Da Ros (2008), Brasil (2011) e Epistein (2011).

A diferenciação em relação às carreiras coercitivas geralmente é menos lembrada, mas também se constituiu um espaço importante para a diferenciação dos círculos judiciais (SCHWARTZ, 1979; SHAPIRO, 1981; KOERNER, 1998). Nesse caso, as diferenças entre Brasil e Estados Unidos são mais acentuadas e denotam vivências bastante distintas entre os magistrados das cortes supremas dos dois países. Das 274 nomeações promovidas à Corte Suprema do Brasil, noventa e sete delas $35,4 \%$ do total - apresentaram alguma vivência na administração da atividade coercitiva do Estado. Esse percentual reduz-se quase à metade no caso norte-americano, perfazendo $18,9 \%$ dos casos. Esses valores por si só seriam suficientes para expor uma diferença importante entre as duas realidades, mas outra dessemelhança é provavelmente mais relevante. Não só o envolvimento dos futuros ministros do STJi-STF foi maior do que os dos justices da USSC na gestão do uso da coerção pelo Estado, como também houve importantes diferenças quanto ao tipo de atividade exercida. No Brasil, a principal forma de contato com a administração da atividade coercitiva do Estado foi a gestão de forças policiais, em cargos como Delegado ou Chefe de Polícia, observando-se $28,1 \%$ dos ministros com esse tipo de vivência antes de ingressar na corte, contra apenas 13,1\% daqueles que tiveram contato com a administração de atividades militares. Nos Estados Unidos, chama a atenção que nenhum dos futuros justices da USSC tenha ocupado cargos de natureza policial antes de ingressar na Suprema Corte do país ${ }^{18}$. Os 21

18 Essa informação pode ser um pouco amenizada caso considere-se que seis justices, apenas 5,4\% do total, foram 
indivíduos, ou $18,9 \%$ do total, que passaram por cargos ligados à administração da coerção nos EUA ocuparam patentes de médias a elevadas - como Capitão, Major ou Coronel - nas Forças Armadas do país, quase sempre em cumprimento ao serviço militar obrigatório e em tempos de guerra, como a II Guerra Mundial, a Guerra Civil ou a própria Guerra de Independência do país.

\section{GRÁFICO 6 - EXPERIÊNCIACOERCITIVA PRÉVIA}

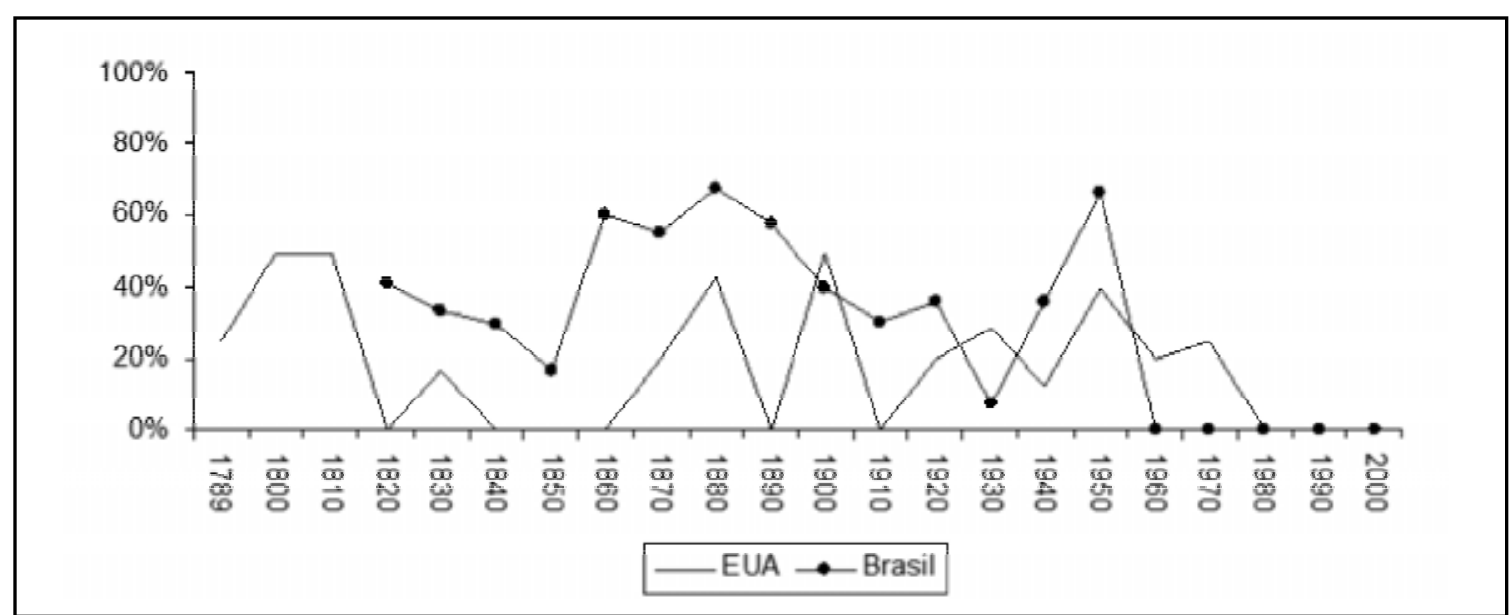

FONTE: O autor, a partir de Lago (2001), Fundação Armando Álvares Penteado (2007), Mello Filho (2007), Marenco dos Santos e Da Ros (2008), Brasil (2011) e Epistein (2011).

Analisando-se a série histórica das duas realidades, no Gráfico 6 acima, observa-se que a diferenciação entre as arenas jurídicas e coercitivas, do ponto de vista da experiência profissional dos integrantes da cortes supremas dos dois países, é um processo praticamente consolidado. No Brasil, desde a década de 1950 não se verificam indivíduos nomeados à Corte Suprema com esse tipo de experiência e desde a década de 1980 nos EUA, sendo que os percentuais são quase sempre reduzidos nesse caso. Em tempo, convém lembrar que tanto no Brasil quanto nos EUA há indivíduos que tiveram tanto experiências nas arenas políticas quanto nas atividades coercitivas antes de ingressarem nos respectivos órgãos de cúpula do poder Judiciário dos dois países. No Brasil, foram nada menos de 59 os que tiveram carreiras jurídicas, políticas e coercitivas $(21,5 \%$ do total), ao passo que nos EUA foram $16-14,4 \%$ do universo de análise.

prefeitos ao longo de suas carreiras. Como se sabe, nos Estados Unidos, o cargo de Prefeito é concomitante ao de chefe de polícia da cidade, o que confere alguma vivência nesse tipo de atividade, ainda que não de maneira exclusiva, como verificado entre os ministros do STJi-STF no Brasil. Todavia, mesmo introduzindo-se essa variável de controle, observa-se que há muito mais integrantes da Corte Suprema com esse tipo de experiência no Brasil do que nos EUA.
Finalmente, é importante apontar um achado de pesquisa que se relaciona a um aspecto frisado ainda no início desse artigo, qual seja, aquele referente ao impacto das diferentes regras de seleção de magistrados no caso brasileiro. De acordo com os dados, a exigência de qualificações para as nomeações, restringindo a escolha da chefia de Estado, aponta exatamente no sentido oposto ao que corriqueiramente se espera. Justamente a regra mais restritiva, a do STJi (envolvendo recrutamento endógeno à carreira judicial e seniority) foi a que apresentou o menor percentual de indivíduos exclusivamente ligados ao mundo jurídico entre os recrutados ao órgão de cúpula do poder Judiciário brasileiro. Durante esse período, apenas $17,7 \%$ dos indivíduos possuíam carreiras ligadas apenas ao mundo jurídico. Contrariamente, a regra mais discricionária das décadas de 1930-1940, que prescindia da confirmação da vontade presidencial pelo Senado, foi a que apresentou o mais elevado percentual de ministros com carreira exclusivamente jurídica, $42,8 \%$. A regra atual, por sua vez, ocupa um espaço intermediário, apresentando 29,4\% com perfil exclusivamente jurídico. Esses achados sugerem que outros fatores devem ser levados em consideração além das regras de nomeação quando se pensa no insulamento de cortes supremas em relação às atividades políticas. Regras referentes 
à própria carreira judicial nas instâncias inferiores do poder Judiciário, estabelecendo limites mais rígidos em relação ao exercício de funções paralelas parecem ser determinantes nesse sentido.

\section{CONCLUSÕES}

Das constatações expostas emerge uma questão relevante a ser discutida. Em diversos trabalhos sobre as origens sociais e a formação da identidade das diferentes profissões jurídicas, alguns autores expõem a emergência da ideologia do profissionalismo como determinante no sucesso desses grupos para que se adote uma postura de intervir politicamente, mas sem identificar-se com o conjunto de forças políticopartidárias existentes. No caso, a construção de uma identidade de grupo vinculada ao exercício de uma função profissionalizada de recorte essencialmente intelectual foi decisiva para a sobrevivência e independência no exercício de suas funções frente ao contexto político.

Como se observa, a reflexão aqui pretendida articula-se diretamente com essa lógica, sendothe complementar. Se a construção da ideologia do profissionalismo é decisiva para que esses grupos sobrevivam influindo politicamente sem apresentarem-se como contendores imediatos, por outro lado, parece pouco crível que tais grupos adquiram poder às expensas dos atores políticos sem que estes estejam de fato dispostos a depositálo nas mãos de indivíduos que não lhes sejam conhecidos e leais politicamente, como juízes profissionais, por exemplo, mesmo que estes se declarem neutros, independentes ou apolíticos.

Os achados deste artigo sugerem que o incremento na profissionalização de magistrados de cortes supremas pode ser explicado em alguma medida como uma função da relevância política desses órgãos, integrada por dois contextos específicos, que forneceriam as bases para a ascensão de indivíduos profissionais a tais postos. O primeiro ocorreria em contextos de forte hegemonia e liga-se à falta de controvérsia no interior das práticas políticas e da profissão jurídica. O segundo estabeleceria-se em um ambiente maior competição política e operaria como uma espécie de estratégia subótima daqueles que promovem a nomeação ao cargo, que buscaria evitar conflitos sérios com os demais atores políticos nesse processo. Ao não agir assim, adotaria-se uma postura de contornos menos partidários, tornando-a mais aceitável ao conjunto de forças políticas existentes e gerando menos controvérsias quanto às futuras decisões daqueles julgadores.

A análise comparativa sugere ainda que um elemento importante - provavelmente uma condição necessária, embora não suficiente - para o incremento da profissionalização na arena jurídica é a própria constituição de uma ordem política que priorize a técnica e o mérito profissional, na qual inexista, por exemplo, o trabalho escravo. Não há espaço para discorrer sobre essa hipótese que mereceria ser trabalhada de maneira mais detalhada em outra oportunidade, mas é interessante observar que praticamente inexistiram indivíduos vinculados apenas às carreiras jurídicas, enquanto cada um dos países permitiu a escravidão em seus respectivos territórios - até 1865 nos EUA e 1888 no Brasil ${ }^{19}$.

Ademais, os achados empíricos deste artigo, particularmente em relação ao caso brasileiro, sugerem que o incremento da profissionalização na arena jurídica não está necessariamente relacionado a um regime político específico, democrático ou autoritário. Na realidade, ele parece encontrar oportunidades para prosperar em ambos contextos, o que de certa maneiras encontra-se em sintonia com a própria ideologia do profissionalismo - constituir um espaço de atuação política independente das arenas tradicionalmente associadas ao efetivo exercício do poder, o que independe, portanto, da natureza do regime político existente.

Nesse sentido, em relação às diferentes regras de seleção dos magistrados, a breve análise realizada é de interesse porque coloca à prova o conventional wisdom existente em boa parte da academia jurídica, de acordo com o qual regras demandando mais qualificações por parte dos candidatos seriam mais desejáveis por evitarem uma alegada partidarização dos tribunais (GUARNIERI \& PEDERZOLI, 1996; EPSTEIN, KNIGHT \& SHVETSOVA, 2001). Ao que parece, portanto, assim como a profissionalização das profissões jurídicas não se encontra necessariamente associado à presença de democracia, como se poderia supor, tampouco regras de

19 Essa observação foi incluída graças aos comentários de Renato Monseff Perissinotto e Maria Izabel Noll, a quem o autor agradece pelas sugestões e leituras atentas. 
recrutamento endógeno às carreiras judiciais sozinhas impedem a nomeação de indivíduos com vínculos políticos mais claros para os órgãos de cúpula da magistratura.

Luciano Da Ros (luciano_da_ros@yahoo.com.br) é Doutorando em Ciência Política pela University of Illinois at Chicago (EUA).

\section{REFERÊNCIAS BIBLIOGRÁFICAS}

ARANTES, R. B. 1997. Judiciário e política no Brasil. São Paulo: Sumaré.

BAUMGARTNER, F. \& JONES, B. 2009. Agendas and Instability in American Politics. $2^{\text {nd }}$ ed. Chicago: University of Chicago.

BONELLI, M. G. 2002. Profissionalismo e política no mundo do Direito: as relações dos advogados, desembargadores, procuradores de justiça e delegados de polícia com o Estado. São Carlos: UFSCAR.

CALDEIRA, G. 1987. Public Opinion and the U.S. Supreme Court: FDR's Court-Packing Plan. American Political Science Review, Los Angeles, v. 81, n. 4, p. 1139-1153, Dec. Disponível em: http://epstein.usc.edu/research/ courses.changecaldeira1.pdf. Acesso em: 20.dez.2011.

CARVALHO, A. B. 2008. State Government, Political Competition and Education Reform: Comparative Lessons from Brazil. Bulletin of Latin American Research, Oxford, v. 27, n. 2, p. 235-254, Mar.

CARVALHO, J. M. 1980. A construção da ordem: a elite política imperial. Rio de Janeiro: Campus.

CLAYTON, C. 1999. The Supreme Court and Political Jurisprudence: New and Old Institutionalisms. In: CLAYTON, C. \& GILLMAN, H. (eds.). Supreme Court Decision-Making: New Institutionalist Approaches. Chicago: University of Chicago.

CUSHMAN, C. 1995. The Supreme Court Justices: Illustrated Biographies, 1789-1995. Washington: Congressional Quarterly.

D’ARAÚJO, M. C. 2007. Governo Lula: contornos sociais e políticos da elite do poder. Rio de Janeiro: Fundação Getúlio Vargas.

ENGELMANN, F. 2008. Estudos no exterior e mediação de modelos institucionais: o caso dos juristas brasileiros. Revista de Sociologia e
Política, Curitiba, v. 16, n. sup., p. 145-157, ago. Disponível em: http://www.scielo.br/ scielo.php? script $=$ sci_pdf\&pid $=$ S0 104 44782008000300011\&lng=en\&nrm=iso\&tlng=pt. Acesso em: 20.dez.2011.

EPP, C. 1998. The Rights Revolution: Lawyers, Activists, and Supreme Courts in Comparative Perspective. Chicago: University of Chicago.

EPSTEIN, L. \& SEGAL, J. 2005. Advice and Consent: the Politics of Judicial Appointments. Oxford: Oxford University.

EPSTEIN, L.; KNIGHT, J. \& MARTIN, A. 2003. The Norm of Prior Judicial Experience and its Consequences for Career Experience Diversity on the U. S. Supreme Court. California Law Review, Berkeley, v. 91, n. 4, p. 903-966, July.

EPSTEIN, L.; KNIGHT, J. \& SHVETSOVA, O. 2001. Comparing Judicial Selection Systems. William \& Mary Bill of Rights Journal, Williamsburg, v. 10, n. 1, p. 7-36. Disponível em: http://epstein.usc.edu/research/conference papers.2001ConCts.pdf. Acesso em: 20.dez.2011.

EPSTEIN, L.; SEGAL, J.; LINDSADT, R. \& STAUDT, N. 2005. The Role of Qualifications in the Confirmation of Nominees to the U. S. Supreme Court. Florida State University Law Review, Tallahassee, v. 32, n. 4, p. 1145-1173. Disponível em: http://epstein.usc.edu/research/ qualified.pdf. Acesso em: 20.dez.2011.

EPSTEIN, L.; WALKER, T.; STAUDT, N.; HENDRICKSON, H. \& ROBERTS, J. 2008. U. S. Supreme Court Justices Database. Disponível: http://epstein.law.northwestern. edu/research/justicesdata.html. Acesso em: 20.dez.2011.

GILLMAN, H. 1993. The Constitution Besieged: The Rise and Demise of Lochner Era Police Powers Jurisprudence. Durham: Duke University. 
2002. How Political Parties Can Use the Courts to Advance Their Agendas: Federal Courts in the United States, 1875-1891. American Political Science Review, Los Angeles, v. 96, n. 3, p. 511-524, Sept.

GUARNIERI, C. \& PEDERZOLI, P. 1996. La puissance des juges: Pouvoir Judiciaire et démocratie. Paris: Michalon.

HALLIDAY, T. 1999. Politics and Civic Professionalism: Legal Elites and Cause Lawyers. Law \& Social Inquiry, Oxford, v. 24, n. 4, p. 1013-1060, Autumn.

HELMKE, G. 2005. Courts Under Constraints: Judges, Generals, and Presidents in Argentina. Cambridge: Cambridge University.

HELMKE, G. \& SANDERS, M. 2006. Modeling Motivations: a Method for Inferring Judicial Goals from Behavior. Journal of Politics, Statesboro, v. 68, n. 4, p. 867-878, Nov.

KECK, T. 2007. Party, Policy, or Duty: Why Does the Supreme Court Invalidate Federal Statutes? American Political Science Review, Los Angeles, v. 101, n. 2, p. 321-338, May. Disponível em: http://faculty.maxwell.syr.edu/ tmkeck/readings/keck_apsr_may_2007.pdf. Acesso em: 20.dez.2011.

KEITH, L. C. 2007. The United States Supreme Court and the Judicial Review of Congress, 1803-2001. Judicature, Des Moines, v. 90, n. 4, p. 166-176. Disponível em: http:// www.ajs.org/ajs/publications/judicature_pdfs/ 904/keith_904.pdf. Acesso em: 20.dez.2011.

KINGDON, J. W. 2003. Agendas, Alternatives, and Public Policies. $2^{\text {nd }}$. New York: Longman.

KOERNER, A. 1998. Judiciário e cidadania na constituição da República brasileira. São Paulo: Hucitec.

1999. Habeas-corpus: prática judicial e controle social no Brasil. São Paulo: IBCCrim.

LAGO, L. 2001. Supremo Tribunal de Justiça e Supremo Tribunal Federal: dados biográficos. Brasília: Supremo Tribunal Federal.

LEMOS, L. B. \& LLANOS, M. 2007. O Senado e as aprovações de autoridades: um estudo comparativo entre Argentina e Brasil. Revista Brasileira de Ciências Sociais, São Paulo, v. 22, n. 64, p. 115-138. Disponível em: http:// www.scielo.br/pdf/rbcsoc/v22n64/ a09v2264.pdf. Acesso em: 20.dez.2011.

LOUREIRO, M. R. 1997. Os economistas no governo. Rio de Janeiro: Fundação Getúlio Vargas.

LYLES, K. 1997. The Gatekeepers: Federal District Courts in the Political Process. Westport: Praeger.

MALLESON, K. \& RUSSELL, P. H. 2006. Appointing Judges in Age of Judicial Power: Critical Perspectives from Around the World. Toronto: University of Toronto.

MARENCO DOS SANTOS, A. \& DA ROS, L. 2008. Caminhos que levam à Corte: carreiras e padrões de recrutamento dos ministros dos órgãos de cúpula do poder Judiciário brasileiro (1829-2006). Revista de Sociologia e Política, Curitiba, v. 16, n. 30, p. 131-149, jun. Disponível em: http://www.scielo.br/pdf/rsocp/ v16n30/09.pdf. Acesso em: 20.dez.2011.

MCGUIRE, K. 2004. The Institutionalization of the U. S. Supreme Court. Political Analysis, Oxford, v. 12, n. 2, p. 128-142. Disponível em: http://www.uwyo.edu/pols/courses/4840/ 9.7-3.pdf. Acesso em: 20.dez.2011.

2005 Are the Justices Serving Too Long? An Assessment of Tenure on the U. S. Supreme Court. Judicature, Des Moines, v. 89, n. 1, p. 8-15. Disponível em: http://www.unc.edu/ $\sim$ kmcguire/papers/tenure.pdf. Acesso em: 20.dez.2011.

MELLO FILHO, J. C. 2007 Notas sobre o Supremo Tribunal: Império e República. Brasília: Supremo Tribunal Federal.

MORSE, R. M. 1988. O espelho de Próspero: cultura e idéias nas Américas. São Paulo: Companhia das Letras.

NAGEL, S. 1961. Political Party Affiliation and Judges' Decisions. American Political Science Review, Los Angeles, v. 55, n. 4, p. 843-850, Dec.

OLIVIERI, C. 2007. Política, burocracia e redes sociais: as nomeações para o alto escalão do Banco Central do Brasil. Revista de Sociologia e Política, Curitiba, v. 15, n. 29, p. 147-168, nov. Disponível em: http://www.scielo.br/pdf/ rsocp/n29/a11n29.pdf. Acesso em: 20.dez. 2011. 
PROVINE, D. M. 1986. Judging Credentials: Nonlawyer Judges and the Politics of Professionalism. Chicago: University of Chicago.

SANTOS, W. G. 1979. Cidadania e Justiça: a política social na ordem brasileira. Rio de Janeiro: Campus.

SCHWARTZ, S. 1979. Burocracia e sociedade no Brasil colonial: a Suprema Corte da Bahia e seus juízes (1609-1751). São Paulo: Perspectiva.

SHAPIRO, M. 1981. Courts: a Comparative and Political Analysis. Chicago: University of Chicago.
TAYLOR, M. 2008. Judging Policy: Courts and Policy Reform in Democratic Brazil. Stanford: Stanford University.

VALE, O. T. 1976. O Supremo Tribunal Federal e a instabilidade político-institucional. Rio de Janeiro: Civilização Brasileira.

VELLASCO, I. A. 2004 As seduções da ordem: violência, criminalidade e administração da justiça: Minas Gerais, século 19. São Paulo: Anpocs.

VIANNA, L. W.; CARVALHO, M. A. R.; MELO, M. P. C. \& BURGOS, M. B. 1999. A judicialização da política e das relações sociais no Brasil. Rio de Janeiro: Revan.

\section{OUTRASFONTES}

BRASIL. SUPREMO TRIBUNAL FEDERAL. Ministros. Disponível em: http://www.stf. jus.br/portal/ministro/ministro.asp. Acesso em: 20.dez.2011.
FUNDAÇÃO ARMANDO ÁLVARES PENTEADO. 2007. Anuário da Justiça. São Paulo: Conjur. 
PROFESSIONAL JUDGES? CAREER PATTERNS FOR MEMBERS OF THE BRAZILIAN (1829-2008) AND UNITED STATES (1789-2008) SUPREME COURTS

Luciano Da Ros

This article compares the career profiles of U.S. and Brazilian supreme court judges throughout the political history of these two countries. For these purposes, we analyze data on professional and juridical experience and the circulation of positions within other branches of State power, including elected offices, prior to Supreme Court appointment. In particular, this examination reveals similarities and differences of professionalization patterns among those who are the height of judicial power in both countries, allowing for discussion of the political bases of this phenomenon within the juridical field. Most significantly, the article suggests that periods of increased recruitment of individuals linked to specifically juridical professions occurs as a response to the strengthening of the courts themselves. In the face of a new stage of increased prominence of these institutions, people who are recognizably qualified in the area become an alternative source of legitimation for the organs themselves, whether in contexts of competition or of the political hegemony of particular groups.

KEYWORDS: Juridical Careers; Selection of Judges; Professionalization; Juridical Professions. 